\title{
Heparanase Expression Correlates with Invasion and Poor Prognosis in Gastric Cancers
}

\author{
Munenori Takaoka, Yoshio Naomoto, Takaomi Ohkawa, Hirokazu Uetsuka, \\ Yasuhiro Shirakawa, Futoshi Uno, Toshiyoshi Fujiwara, Mehmet Gunduz, \\ Hitoshi Nagatsuka, Motowo Nakajima, Noriaki Tanaka, and Minoru Haisa
}

Departments of First Surgery (MT, YN, TO, HU, YS, FU, TF, NT, MH) and Oral Pathology and Medicine (MG, HN), Graduate School of Medicine and Dentistry, Okayama University, Okayama, and Tsukuba Research Institute (MN), Novartis Pharma K.K. Tsukuba, Japan

\begin{abstract}
SUMMARY: Degradation of basement membrane and extracellular matrix structures are important features of the metastatic process of malignant tumors. Human heparanase degrades heparan sulfate proteoglycans, which represent the main components of basement membranes and the extracellular matrix. Because of the role of heparanase in tumor invasion and metastasis, we examined heparanase expression in primary gastric cancers and in cell lines derived from gastric cancers by immunohistochemistry and RT-PCR, respectively. Four of seven gastric cancer cell lines showed heparanase mRNA expression by RT-PCR. Heparanase protein was detected in both the cytoplasm and the nucleus of heparanase mRNA-positive cells by immunohistochemical staining. Heparanase expression was confirmed in $35(79.5 \%)$ of 44 gastric tumor samples by immunohistochemical staining. However, no or weak heparanase expression was detected in normal gastric mucosa. In situ hybridization showed that the mRNA expression pattern of heparanase was similar to that of the protein, suggesting that increased expression of the heparanase protein at the invasive front was caused by an increase of heparanase mRNA in tumor cells. Analysis of the clinicopathologic features showed stronger heparanase expression in cases of huge growing tumors, extensive invasion to lymph vessels, and regional lymph node metastasis. In gastric cancer, patients with heparanase expression showed significantly poorer prognosis than those without such expression $(p=0.006)$. In conclusion, our findings suggest that high expression of heparanase in gastric cancer is a strong predictor of poor survival. (Lab Invest 2003, 83:613-622).
\end{abstract}

$G$ astric cancer remains one of the most common cancer types in the world, although its incidence has gradually decreased in recent years in many countries. The clinical outcome for gastric cancer patients remains poor, with a 5-year survival rate of only $20 \%$ in all stages (Ries et al, 2000); a mere $40 \%$ of all patients respond to surgical intervention (Ajani et al, 1995). Gastric cancers form various differentiated patterns and display invasive and metastatic varieties. One of the essential processes of invasion and metastasis of gastric cancer is the degradation of basement membranes and extracellular matrix structures (Tahara, 1995, 2000). Specific enzymes produced by cancer cells and activated by certain signals degrade extracellular matrixes and basement membranes. Previous studies have identified several extracellular matrix-degrading enzymes, such as matrix metalloproteinases (MMPs), that are involved in the processes of invasion and metastasis of gastric cancers (Adachi et al, 1998; Schwartz, 1996; Senota et al, 1998; Tahara, 1995). Heparan sulfate and heparan

\section{DOI: 10.1097/01.LAB.0000067482.84946.BD}

Received November 12, 2002.

Address reprint requests to: Dr. Yoshio Naomoto, First Department of Surgery, Graduate School of Medicine and Dentistry, Okayama University, 2-5-1, Shikata-cho, Okayama 700-8558, Japan. E-mail: ynaomoto@md.okayama-u.ac.jp sulfate proteoglycans, which are important structural components of the extracellular matrix and the external surface of cell membranes, play a major role in cell-cell and cell-extracellular matrix interactions. Heparan sulfate-degrading endoglycosidase activity associated with metastatic tumor cells was first identified in mouse B16-F10 melanoma cells cultured on an extracellular matrix of vascular endothelial cells (Nicolson et al, 1983). Furthermore, a good correlation was observed between the heparan sulfate-degrading endoglycosidase activity and the lung colonization potential of murine B16 melanoma sublines (Nakajima et al, 1983).

The cleavage of heparan sulfate chains also induces cell growth, migration, and angiogenesis by releasing heparan sulfate-bound cytokines and growth factors, such as basic fibroblast growth factor, from cell surfaces and extracellular matrixes (Vlodavsky et al, 1991). Human heparanase, an endoglycosidase, specifically involved in cleaving heparan sulfate, was cloned recently, and its characteristic functions related to the invasion and metastasis of cancer cells have been reported (Hulett et al, 1999; Kussie et al, 1999; Toyoshima and Nakajima, 1999; Vlodavsky et al, 1999). The activity of heparanase closely correlates with tumor invasion, metastasis (Marchetti et al, 2000; Nakajima, 1992; Parish et al, 2001; Vlodavsky et al, 1999; Walch and Marchetti, 1999), and inflammatory 
reactions (Bartlett et al, 1995; Mollinedo et al, 1997), and the enzyme is moderately up-regulated, especially in metastatic cancers. Based on previous reports, we postulated that heparanase would be involved at invasion and metastasis of gastric cancers cells. In this regard, Friedmann et al (2000) identified the expression of heparanase in dysplastic and neoplastic colonic mucosa and the evidence for its role in colonic carcinogenesis.

Analysis of heparanase mRNA expression by RTPCR was recently reported in gastrointestinal cancers (Endo et al, 2001; Inoue et al, 2001). However, analysis of heparanase protein expression in gastric cancers by immunohistochemistry has not been reported so far. In the present study, we examined the expression of heparanase protein and mRNA in primary gastric cancers and cell lines by immunohistochemistry and RT-PCR, respectively. Our study identified for the first time the relationship between increased heparanase protein expression and poor clinicopathologic characteristics in gastric cancers.

\section{Results and Discussion}

\section{Detection of Heparanase mRNA in Gastric Cancer Cell Lines}

First, we performed RT-PCR to detect heparanase mRNA in gastric cancer cell lines. Four of seven gastric cancer lines (MKN-1, MKN-7, MKN-28, and $\mathrm{MKN}-45)$ showed heparanase mRNA expression, whereas expression was not detectable in three cell lines (NUGC3, A521, and SH-10-TC) (Fig. 1).

\section{Localization of Heparanase Protein in Gastric Cancer Cells}

To demonstrate the difference in heparanase expression between MKN-1 (heparanase mRNA positive) and NUGC3 (heparanase mRNA negative), we performed immunohistochemistry. Heparanase protein was detected at in the cytoplasm and nucleus in $\mathrm{MKN}-1$ cells (Fig. 2A), whereas it was not seen in NUGC3 cells (Fig. 2B). To our knowledge, no studies have previously demonstrated intranuclear localization of heparanase protein in cancer cells. In cultured cells, heparanase protein was stained especially in the mitotic phase of gastric cancer cell lines (Fig. 2A). However, whether nuclear heparanase is functionally important and the nature of such function, remains unresolved

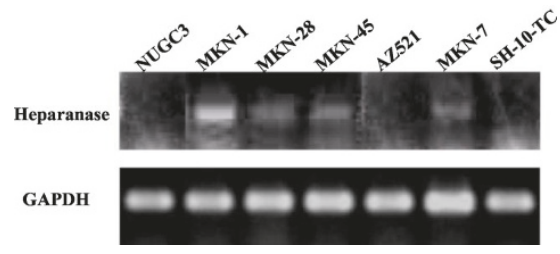

Figure 1.

Heparanase expression in cultured gastric cancer cell lines. Four of seven gastric cancer lines (MKN-1, MKN-7, MKN-28, and MKN-45) showed heparanase mRNA expression.

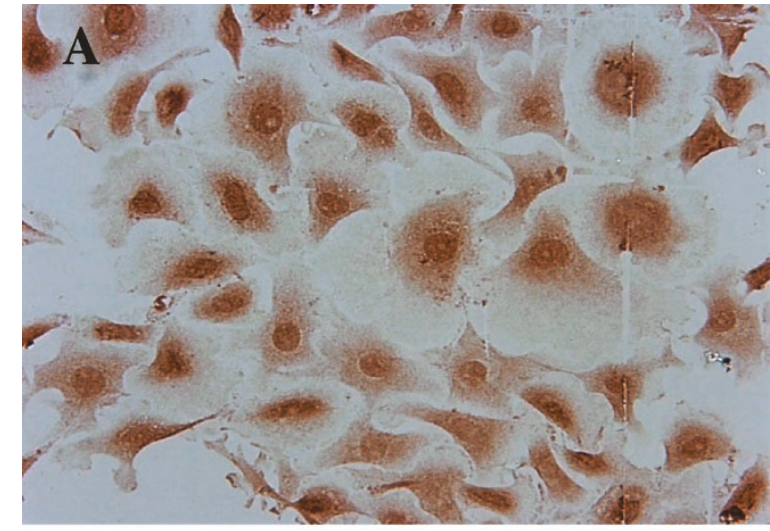

B

Figure 2

Heparanase protein expression in cultured gastric cancer cell lines. A, Heparanase protein was detected by immunohistochemical staining at the cytoplasm and nucleus in heparanase mRNA-positive cells (MKN-1). B, Expression was not seen in heparanase mRNA-negative cells (NUGC3).

\section{Immunohistochemical Staining of Tumor Samples}

We immunohistochemically stained gastric normal mucosa, cancer tissue, and its stroma with monoclonal anti-heparanase antibody to determine the exact area(s) with strong heparanase expression. We also examined heparanase expression in metastatic tumors of gastric cancer. In normal mucosa, heparanase was not expressed in the mature zone (Fig. 3A). However, some of the proliferating zone of epithelial cells in the normal gastric mucosa showed faint heparanase expression (not shown). In early gastric carcinoma, weak heparanase expression was detected in some of cancer cells (Fig. 3B). In contrast, advanced cancers with invasion beyond the muscular layer showed a significantly stronger expression of heparanase protein (Fig. 3C). In papillary type carcinoma, heparanase expression was detected along the cell membrane (Fig. 3D). Cancer cells invading into lymph vessels also demonstrated strong heparanase expression (Fig. 3E). In particular, heparanase expression was enhanced in massive invading tumor cells and at the edge of such masses of tumor cells (Fig. 4, $A$ and $B$ ). The most intensely stained region was the invasion front of tumors (Fig. 4A). Heparanase expression was also found at the edge of metastatic masses in regional lymph nodes (not shown) and liver (Fig. 4C). These immunostaining characteristics resembled the 

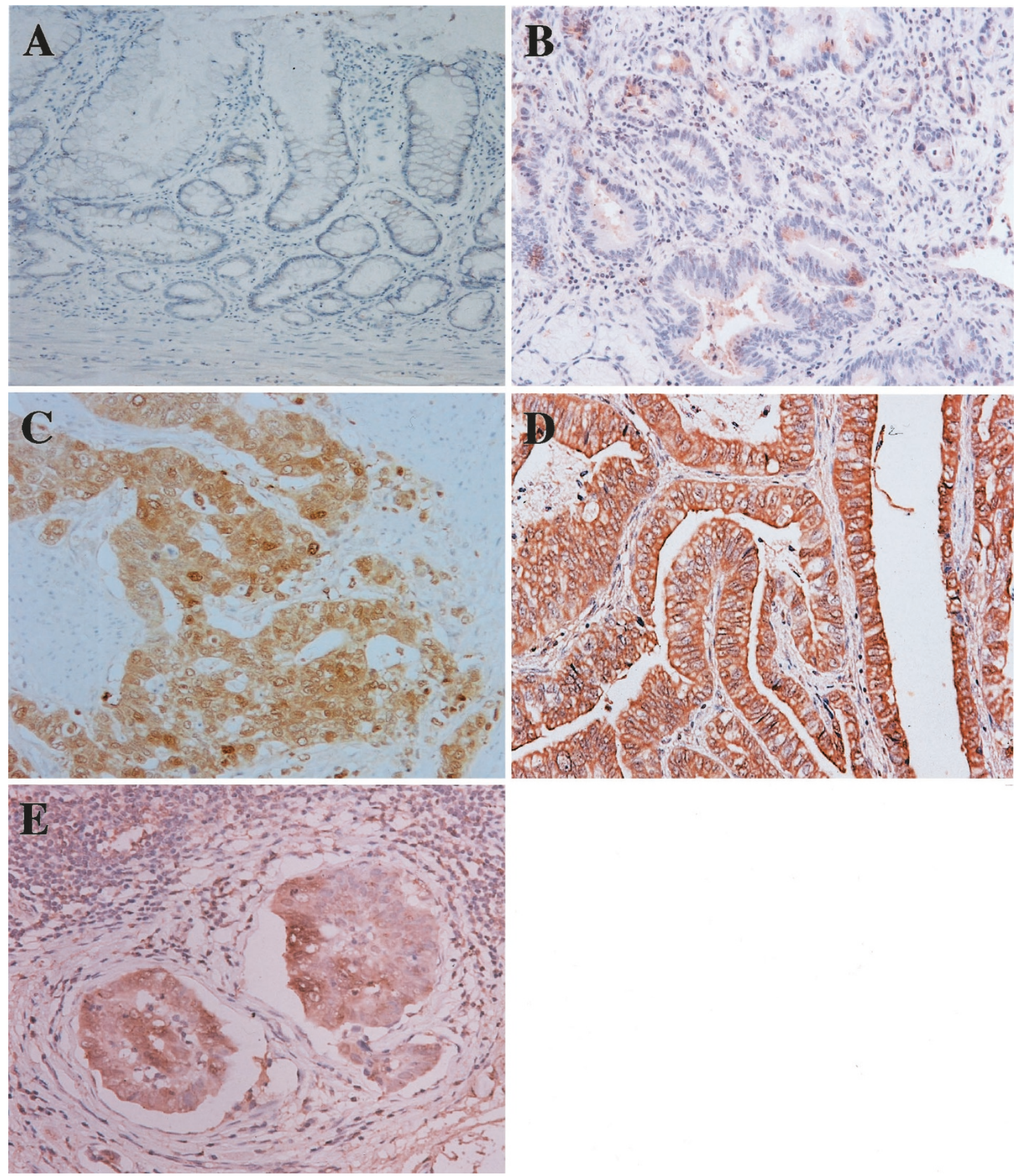

\section{Figure 3.}

Immunohistochemical analysis of heparanase expression. A, Mature normal gastric epithelium does not have heparanase $(\times 200)$. B, Early stage cancer shows scarce staining for heparanase in tumor cells $(\times 200)$. C, Advanced carcinoma has strong expression in its cytoplasm $(\times 200)$. D, Papillary carcinoma shows heparanase expression at the cell membrane $(\times 200)$. E, Cancer cells invading into lymph vessels also have strong heparanase expression $(\times 200)$.

pattern of MMP-7 staining in colon cancers (Yamamoto et al, 1999).

The absence of heparanase expression in some cells but up-regulation in others within the same tissue of tumors seemed to be under random regulation in each cell. However, based on a close observation of an extracellular milieu, heparanase expression seemed to be regulated by the cell- extracellular matrix interaction in the tumor environment. In fact, MMP-7 is up-regulated by stimulation of fibronectin (Yamamoto et al, 1994). Our results showed that heparanase was expressed in vascular endothelial cells, fibroblasts, and macrophages in stromal tissue (Fig. 4, D and E). Friedmann et al (2000) reported similar expression of heparanase in the stroma of colorectal cancers. 

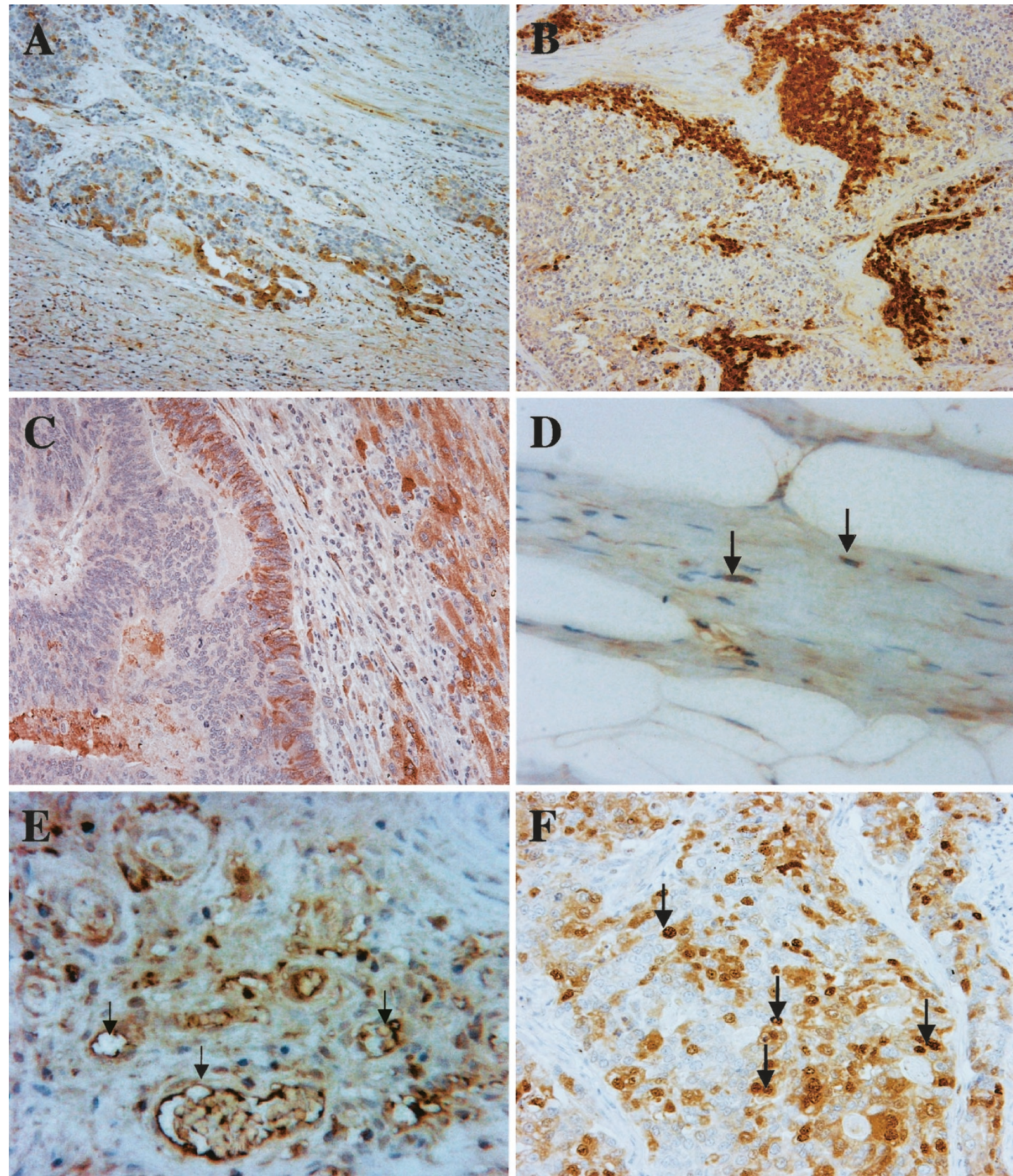

Figure 4.

Characteristics of heparanase protein localization in gastric cancer tissues. Heparanase expression was enhanced in the invasive front $(A ; \times 100)$ and in the edge of cancer tissues of primary gastric tumors $(B ; \times 200)$ and metastatic tumor detected in the liver $(C ; \times 200)$. In the stroma of malignant gastric tissue, the vascular endothelium $(D$, arrows; $\times 200)$ and fibroblasts $(E$, arrows; $\times 200)$ in close proximity to the tumor also showed heparanase expression. Heparanase was localized not only in the cell membrane and cytoplasm but also in the nucleus in surgical specimens $(\mathrm{F} ; \times 200)$.

Although heparanase expression was mainly found in the cytoplasm of cancer cells, we also detected similar staining in the nuclei of cancer cells (Fig. 2A and 4F). Our immunohistochemical studies showed overexpression of heparanase protein mainly in the nuclei of tumor cells located in the invasion front, suggesting that heparanase contributes at least in part to the growth and invasion of gastric tumors.

\section{Expression Pattern of the Heparanase mRNA}

Heparanase could originate in platelets and fibroblasts and be deposited at sites of tissue injury. To investi- 
gate the origin of heparanase and the correlation between the localization of heparanase protein and mRNA, in situ hybridization of heparanase from eight representative samples of gastric cancer was performed. As shown in Figure 5, the mRNA expression pattern of heparanase was similar to that of the protein. No positive labeling of heparanase mRNA was identified in normal mucosal epithelium, whereas tumor tissues showed positive labeling of heparanase mRNA. In particular, tumor cells demonstrated strong labeling at the invasive front. Fibroblasts in stromal tissue near the tumor mass also showed positive heparanase labeling.

\section{Correlation Between Heparanase Expression and Clinicopathologic Factors Indicating Its Role in Invasion and Metastasis}

The clinicopathologic features analyzed in the present study are listed in Table 1. Heparanase tended to be intensely expressed in tissues with the following features: (1) massive invasion beyond the deep layer $(p<$ $0.0001)$, (2) the presence of regional lymph node metastasis ( $p<0.02)$, (3) the presence of late stages (Stages III and IV) $(p=0.0004)$, and (4) the presence of lymph vessel invasion $(p=0.02)$. As seen by the results of immunohistochemistry, heparanase expression was significantly strong in the invasion front and in proliferating cells. All of the 11 patients with distant metastases showed positive heparanase expression, whereas 24 (73\%) of 33 patients without such metastasis stained positively for heparanase protein.

\section{Correlation Between Heparanase Expression and Prognosis}

Finally, we examined the correlation between heparanase protein expression and the prognosis of patients with gastric cancer. Statistical analysis showed significantly poor prognosis in patients with immunohistochemically detected heparanase-expressing gastric cancers (Fig. 6, $p=0.006$ ). All patients with poor prognosis died of cancer recurrence or had recurrence after surgery. After 50 months of follow-up, only $34 \%$ of patients with positive heparanase expression survived, whereas $89 \%$ of heparanase-negative patients survived.

Heparanase mRNA expression was recently examined in clinical digestive malignancies by RT-PCR (Inoue et al, 2001). In that study, approximately $60 \%$ of
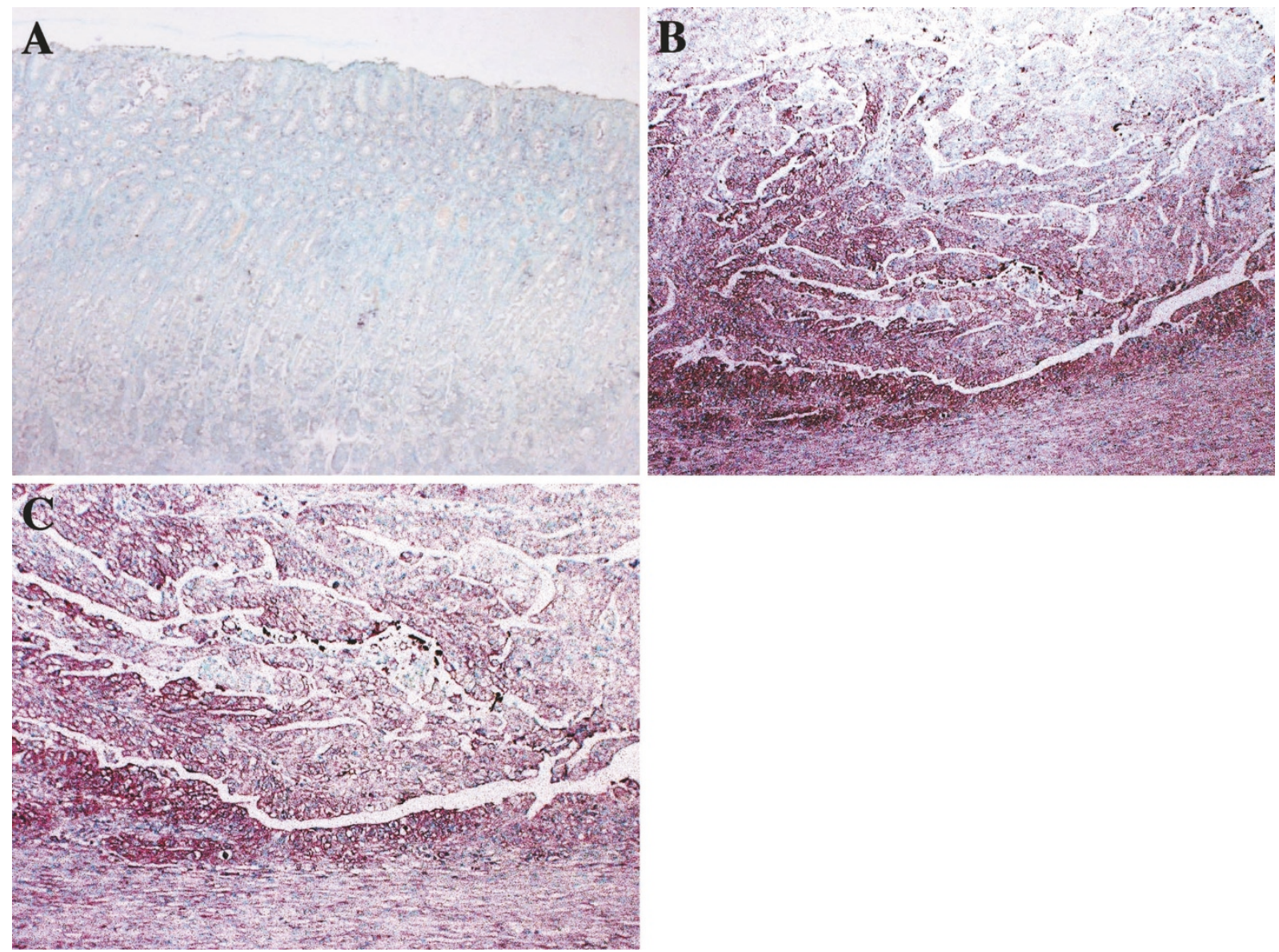

\section{Figure 5.}

Heparanase mRNA (in situ hybridization) in gastric carcinoma. Positive labeling is purple. A, Normal gastric mucosa does not have heparanase gene expression $(\times 70)$. $B$, Tumor cells show strong expression of the heparanase mRNA $(\times 70)$. C, Tumor cells at the invasive front demonstrated much stronger expression of the heparanase gene $(\times 140)$. 
Table 1. Association of Heparanase Expression with Clinicopathologic Characteristics

\begin{tabular}{|c|c|c|c|c|}
\hline \multirow[b]{2}{*}{ Variable } & \multirow[b]{2}{*}{ Category } & \multicolumn{2}{|c|}{ Heparanase } & \multirow[b]{2}{*}{$p$ value } \\
\hline & & Positive $(N=35)^{a}$ & Negative $(N=9)^{a}$ & \\
\hline \multirow[t]{3}{*}{ Differentiation } & Well & 7 & 4 & NS \\
\hline & Moderate & 13 & 3 & \\
\hline & Poor & 15 & 2 & \\
\hline \multirow[t]{4}{*}{ Depth of invasion } & $\mathrm{T} 1$ & 0 & 5 & $<0.0001$ \\
\hline & $\mathrm{T} 2$ & 16 & 3 & \\
\hline & T3 & 17 & 1 & \\
\hline & $\mathrm{T} 4$ & 2 & 0 & \\
\hline \multirow[t]{2}{*}{ Lymph node metastasis (N) } & - & 6 & 5 & 0.0176 \\
\hline & + & 29 & 4 & \\
\hline \multirow[t]{2}{*}{ Distant metastasis (M) } & - & 24 & 9 & 0.0521 \\
\hline & + & 11 & 0 & \\
\hline \multirow[t]{2}{*}{ TNM stage } & I, II & 12 & 9 & 0.0004 \\
\hline & III, IV & 23 & 0 & \\
\hline \multirow[t]{2}{*}{ Lymph vessel invasion } & - & 2 & 3 & 0.0199 \\
\hline & + & 33 & 6 & \\
\hline \multirow[t]{2}{*}{ Venous vessel invasion } & - & 15 & 7 & NS \\
\hline & + & 20 & 2 & \\
\hline
\end{tabular}

NS, not significant.

${ }^{a}$ Positive indicates the detection of the heparanase protein signaling in more than $10 \%$ of carcinoma cells at the invasive front and negative indicates the staining of no or less than $10 \%$ of carcinoma cells with the antibody at the invasive front.

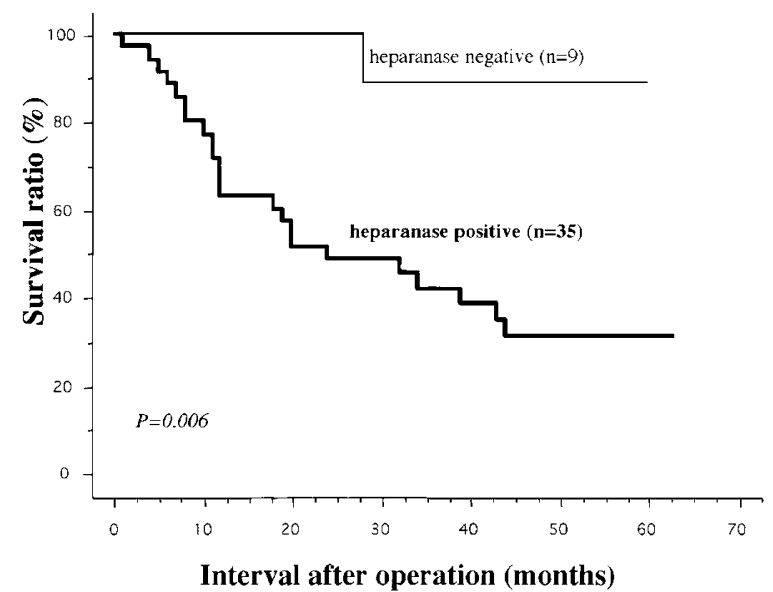

Figure 6 .

Heparanase expression and survival rate of patients. Kaplan-Meier analysis showed significantly poor survival in patients with positive heparanase expression as compared with patients with negative heparanase expression ( $p$ $=0.006)$. After 50 months of follow-up, only $34 \%$ of patients with positive heparanase expression survived, whereas $89 \%$ of patients with negative heparanase expression survived.

gastric cancer cases showed high expression as compared with normal counterparts; expression was approximately $9 \%$ and $19 \%$ for colorectal and esophageal cancers. Moreover, a considerable number of these esophageal and colorectal cancers showed decreased expression as compared with normal counterparts. The authors did not find differences in clinicopathologic factors, including prognosis, between high- and low-expression cases of each cancer type. This study suggested that the heparanase expression status may differ among gastrointestinal cancers. In another recent study, heparanase mRNA expression was reported to be significantly higher than that in normal tissues, and venous invasion was frequent in the heparanase mRNA-positive cancer tissues.

However, these two previous studies examined mRNA expression by RT-PCR. Normal cells such as platelets, fibroblasts, and vascular endothelial cells can produce heparanase. To clarify the origin of the heparanase, we performed in situ hybridization. Most of the heparanase originated in tumor cells, especially at the invasive front. Moreover we used immunohistochemical staining for detection of heparanase protein. Immunohistochemical study and in situ hybridization, which directly show the origin of the mRNA and protein component, would be more representative than RT-PCR. In fact both mRNA and protein expression of heparanase demonstrated similar patterns and locations, suggesting the biologic role of heparanase in the metastatic progress of gastric cancer. Venous vessel invasion in our study was not different between heparanase-positive and -negative cases. However, heparanase-positive cases showed deeper tumor invasion and higher lymph node metastasis in comparison with heparanase-negative cases.

Our and previous functional analyses proved the biologic role of heparanase in the invasion of human tumors (Hulett et al, 1999; Uno et al, 2001; Vlodavsky et al, 1999). Nakajima et al (1983) showed that heparanase activity correlated with the lung colonization potential of murine B16 melanoma. Marchetti et al (2000) reported that astrocytes significantly contributed to the brain colonization of melanoma cells via heparanase-driven modalities. Although it is not known what causes the tumor cells to express heparanase protein, some genetical changes in the hepara- 
nase gene or in genes that control the heparanase pathways could be responsible for this during the progress of the tumor. Molecular changes in tumor suppressor genes or oncogenes are thought to be involved in the carcinogenic pathway from normal cells to cancer. We speculate that heparanase is involved during the tumor progress from early to advanced cancer. In fact our analysis showed less heparanase protein expression in early cancer but increased expression in advanced cancer. Although it is difficult to determine whether the appearance of heparanase is the reason for or the consequence of tumor progress, previous analysis and our current study suggest that the biologic role of heparanase is likely to be the reason for the progress of the tumor. In our study, no significant difference was detected between heparanase- negative and -positive cases in terms of distant metastasis, although there was a higher metastatic tendency in heparanase-positive cases.

Invading cells, particularly metastatic tumor cells and leukocytes, traverse extracellular matrix barriers and basement membranes by deploying a battery of degradative enzymes. Among the enzymes degrading the extracellular matrix, heparanase has been thought to contribute to the malignant potential of tumor cells (Parish et al, 2001). Nuclear factor-kappa B (NF- $\kappa$ B) modulates the expression of extracellular matrix proteins such as MMPs, and blockade of the NF- $\kappa$ B signal results in the down-regulation of MMP-9 and heparanase (Andela et al, 2000). On the other hand, c-met, a hepatocyte growth factor receptor modulating NF- $\kappa \mathrm{B}$ related to the extension of gastric cancer, is thought to be one of the prognostic factors in gastric cancer (Tacchini et al, 2000). Indeed, gastric cancers expressing c-met correlate with poor differentiation and prognosis (Carneiro and Sobrinho-Simoes, 2000; Nakajima et al, 1999). Together with the report that $\mathrm{NF}-\kappa \mathrm{B}$ is up-regulated by the binding of hepatocyte growth factor to c-met, these reports suggest that heparanase may be up-regulated by signal transduction through the c-met pathway in heparanaseoverexpressing gastric cancers.

Nakajima (1992) reported that heparanase activity in the serum of patients with melanoma was more than double that in healthy volunteers. Based on the results of recent studies, heparanase enzyme could be an important target for the development of new antimetastatic and anti-inflammatory drugs (Finkel, 1999; Lapierre et al, 1996; Miao et al, 1999; Nakajima et al, 1991; Parish et al, 1999). In this regard, we recently showed that forced expression of human heparanase enhanced tumor cell invasiveness in vitro and that this invasive ability was significantly reduced by inhibiting heparanase expression using an adenovirus-mediated antisense gene-delivery strategy (Uno et al, 2001). Moreover, injection of recombinant adenoviruses carrying antisense-oriented heparanase cDNA into the pleural space reduced the incidences of tumor cell dissemination and tumor nodules compared with control mice (Uno et al, 2001). Our results emphasize the importance of analysis of the heparanase gene for the prognosis of gastric cancers and for its future use as a target for the development of antimetastatic drugs.

\section{Materials and Methods}

\section{Cells}

Seven gastric cancer cell lines (NUGC3, MKN-1, MKN-7, MKN-28, MKN-45, A521, and SH-10-TC) were used for RT-PCR. Three (MKN-7, A521, and $\mathrm{SH}-10-\mathrm{TC})$ were obtained from the Cell Resource Center for Biomedical Research, Institute of Development, Aging and Cancer, Tohoku University. The NUGC3 cell line was obtained from the Cancer Chemotherapy Center, Japanese Foundation for Cancer Research, Tokyo. The other three cell lines (MKN-1, $\mathrm{MKN}-28$, and $\mathrm{MKN}-45$ ) were purchased from Dainippon Pharmaceutical Company, Ltd., Osaka, Japan. They were cultured in suitable medium supplemented with $10 \%$ fetal bovine serum and $0.1 \%$ penicillin/ streptomycin and maintained at $37^{\circ} \mathrm{C}$ in an atmosphere of $5 \% \mathrm{CO}_{2}$. The pellets of cells collected by treatment with $0.25 \%$ trypsin were used for total RNA extraction. Cells $\left(5.0 \times 10^{4}\right)$ of heparanase-negative (NUGC3) and heparanase-positive (MKN-1) cell lines were seeded into each chamber on silanized slides (Nalge Nunc International) and incubated in $5 \% \mathrm{CO}_{2}$ for 48 hours for immunohistochemical staining.

\section{Tumor Samples}

For immunohistochemical staining we used forty-four gastric cancers resected and stored as paraffinembedded tissue blocks at Okayama University Hospital between 1991 and 1999. The clinicopathologic characteristics were evaluated according to guidelines of the Union Internationale Contre le Cancer.

\section{RT-PCR}

RNA was isolated with RNA zolB (Tel-Test, Inc.) using the protocol recommended by the manufacturer and was quantitated by UV absorption. After reverse transcription of $2 \mu \mathrm{g}$ of total RNA by oligo(dT) priming, the resulting single-strand cDNA was amplified using the GeneAmp RNA PCR Kit (Perkin Elmer). Oligonucleotide primer pairs for heparanase (5'-TTC GAT CCC AAG AAG GAA TCA AC-3' and 5'-GTA GTG ATG CCA TGT AAC TGA ATG-3) and for GAPDH (5'-CAG CCG AGC CAC ATC-3' and 5'-TGA GGC TGT TGT CAT ACT TCT-3') were used for RT-PCR. Two microliters of each $\mathrm{RT}$ reaction was amplified in a $50-\mu \mathrm{l}$ mixture containing $1.2 \mathrm{mM} \mathrm{MgCl}_{2}, 1 \times$ PCR buffer, $200 \mu \mathrm{M}$ of each dNTP, $20 \mathrm{pmol}$ of each primer, and $1.25 \mathrm{U}$ of Amplitaq gold DNA polymerase (Perkin Elmer). For heparanase cDNA amplification, initial denaturation at $95^{\circ} \mathrm{C}$ for 10 minutes was followed by 40 cycles of a denaturation step at $95^{\circ} \mathrm{C}$ for 45 seconds, an annealing step at $60^{\circ} \mathrm{C}$ for 1 minute, and an extension step at $72^{\circ} \mathrm{C}$ for 1 minute. A final extension step at $72^{\circ} \mathrm{C}$ for 7 minutes was added. The same PCR conditions were performed for the amplification of GAPDH, except that 30 cycles were run. Ten microliters of the 
amplified products was separated by $1 \%$ agarose gel electrophoresis and then the gels were incubated in $1 \%$ TAE buffer with SYBR Gold nucleic acid gel stain (Molecular Probes, Eugene, Oregon). A 585-bp band for heparanase and a 300-bp band for GAPDH in the stained gel were observed in the transilluminator.

\section{Immunohistochemistry}

Heparanase staining was performed using the Histofine SAB PO kit (Nichirei, Tokyo) as reported previously (Shirakawa et al, 2000). Briefly, sections (3 $\mu \mathrm{m})$ mounted on silanized slides were deparaffinized and rehydrated and endogenous peroxidase activity was blocked using $3.0 \% \mathrm{H}_{2} \mathrm{O}_{2}$ in methanol for 15 minutes. Antigen retrieval on paraffin sections was performed by heating three times in $10 \mathrm{~mm}$ citrate buffer solution (pH 6.0) in a microwave. After blocking of nonspecific reactivity with rabbit serum for 10 minutes at room temperature, sections were incubated overnight at $4^{\circ} \mathrm{C}$ with the anti-human heparanase mouse mAb. Identification of the distribution of the primary antibody was achieved by subsequent application of a biotinylated antiprimary antibody and streptavidin peroxidase. Immunostaining was developed using DAB/ $\mathrm{H}_{2} \mathrm{O}_{2}$ solution (Histofine DAB substrate kit; Nichirei), and sections were counterstained with Mayer's hematoxylin. As a negative control, some sections were subjected to normal serum blocking and omission of the primary antibody. Immunostaining signals at the invasive front were scored by two independent microscopic observers without knowledge of the patients' clinicopathologic features. Each microscopic observation included two random sections from the invasive front. The scores were calculated as the total number of stained cells divided by the total number of carcinoma cells. Cases were considered positive when more than $10 \%$ of the carcinoma cells at the invasive front were stained with the antibody.

\section{Tissue and Probe Preparation for In Situ Hybridization}

The specimens were immersed in 4\% paraformaldehyde solution in phosphate buffer. All fixed specimens were embedded in paraffin, and $4-\mu \mathrm{m}$ sections were prepared. Digoxigenin-11-UTP-labeled single-strand RNA probes were prepared using a DIG Labeling Kit (Roche Diagnostics GmbH, Penzberg, Germany) according to the manufacturer's instructions. For generation of the heparanase probe, a 571-bp fragment of human heparanase cDNA (bases 261-832 of the total cDNA [Gene Bank Accession No. AF144325]) was obtained by RT-PCR and was subcloned into pCR21 (Invitrogen).

\section{In Situ Hybridization Procedure}

The sections were deparaffinized, rehydrated, and incubated with $3 \mathrm{mg} / \mathrm{ml}$ of proteinase K (Roche Diagnostics) in $10 \mathrm{~mm}$ Tris- $\mathrm{HCl}$ (pH 8.0) and $1 \mathrm{~mm}$ EDTA for 10 minutes at $37^{\circ} \mathrm{C}$. Acetylation of the sections was performed by incubating with freshly prepared $0.25 \%$ aceticanhydride in $0.1 \mathrm{~m}$ triethanolamine- $\mathrm{HCl}$ buffer (pH 8.0) for 10 minutes at room temperature.

The hybridization solution contained $50 \%$ deionized formamide, $10 \%$ dextran sulfate, $1 \times$ Dehardt's solution, $600 \mathrm{~mm} \mathrm{NaCl}, 0.25 \%$ SDS, $250 \mathrm{mg}$ per $\mathrm{ml}$ of Escherichia coli tRNA (proteinase treated) $10 \mathrm{~mm}$ dithiothreitol, and 0.1 to $2.0 \mathrm{mg} / \mathrm{ml}$ of digoxigenin-UTPlabeled RNA probe. The probe was placed on the sections and covered by parafilm and incubated at $50^{\circ} \mathrm{C}$ for 16 hours in a moisture chamber. After hybridization, the slides were incubated with $50 \%$ formamide in $2 \times \mathrm{SSC}$ for 30 minutes at $50^{\circ} \mathrm{C}$ to remove the excess probe. The slides were incubated with $2 \times$ SSC and $0.2 \times$ SSC for 15 minutes twice at $50^{\circ} \mathrm{C}$.

The washed slides were incubated with DIG buffer 1 (100 mm Tris- $\mathrm{HCl}, \mathrm{pH} 7.5,150 \mathrm{~mm} \mathrm{NaCl}$ ) for 60 minutes at room temperature. A $100 \mu \mathrm{l} / \mathrm{cm}^{2}$ specimen of diluted polyclonal sheep anti-digoxigenin Fab fragment (1:1000) in DIG buffer 1 was mounted on the sections and incubated for 30 minutes at room temperature. Coloring solution containing $337.5 \mu \mathrm{g} / \mathrm{ml}$ of nitro blue tetrazolium and $165 \mu \mathrm{g} / \mathrm{ml}$ of 5 -bromo-4chloro-3-indolyl phosphate in DIG buffer $3(100 \mathrm{~mm}$ tris- $\mathrm{HCl}, \mathrm{pH}$ 9.5, $100 \mathrm{~mm} \mathrm{NaCl}, 50 \mathrm{~mm} \mathrm{MgCl}_{2}$ ) was mounted on the sections and incubated at room temperature or $37^{\circ} \mathrm{C}$ until the signal-noise ratio was maximum. The slides were mounted with counterstaining by methyl green. The controls included (a) hybridization with the sense (mRNA) probe, (b) RNase treatment $(20 \mathrm{mg} / \mathrm{ml})$ hybridization, and (c) the use of neither antisense nor antidigoxigenin antibody. None of the controls showed positive signals.

\section{Antibody}

$\mathrm{mAb}$ raised against the recombinant human heparanase was provided by Dr. Shunichiro Taniguchi, Molecular Oncology and Angiology, Angio-Aging Research Division, Research Center on Aging and Adaptation, Shinshu University Medical School, Matsumoto, Japan. Recombinant heparanase was produced by the baculovirus/insect cell expression system using human heparanase cDNA cloned from the cDNA library of SV40-transformed WI38 fibroblasts (Toyoshima and Nakajima, 1999). The hybridoma cells were produced by fusion of SP2 mouse myeloma cells with splenocytes prepared from Balb/c mice, which were immunized with recombinant heparanase. The $\mathrm{mAb}$ used in our study was selected by enzyme immunoassay, Western blot, and heparanase inhibition assay. Briefly, protein samples (10 $\mu \mathrm{g}$ of protein per lane) were separated by $10 \%$ SDS-PAGE and transferred to a polyvinylidene difluoride membrane (Immobilon-P, Millipore, Tokyo). The membrane was blocked with 5\% BSA in TBSN (50 mm Tris- $\mathrm{HCl}, \mathrm{pH}$ 7.4, $150 \mathrm{~mm} \mathrm{NaCl}$, and $0.2 \%$ Nonidet P-40) for 1 hour and incubated with anti-heparanase antibody at a 1:500 dilution in 3\% BSA in TBSN for 1 hour at room temperature. After repeating a 5-minute wash four times with TBSN, the membrane was incubated with peroxidase-labeled anti-rabbit Ig antibody (Amersham 
Life Sciences) at 1:5000 dilution in 3\% BSA in TBSN for 20 minutes, followed by washing as described above. The immunoreactive bands were visualized using the ECL Western blotting detection kit. Western blot analysis demonstrated that the $\mathrm{mAb}$ reacted with both the 65-kDa proform and the 53-kDa mature form of human recombinant heparanase. Reactivity was also confirmed with natural human heparanase purified from SV40-transformed WI38 fibroblasts and A375M human melanoma cells (Fig. 7).

\section{Statistical Analysis}

Heparanase expression was correlated with various clinicopathologic parameters using the $\chi^{2}$ test. Overall survival was calculated using the Kaplan-Meier method and compared by log-rank test. A $p$ value $<$ 0.05 was considered significant.

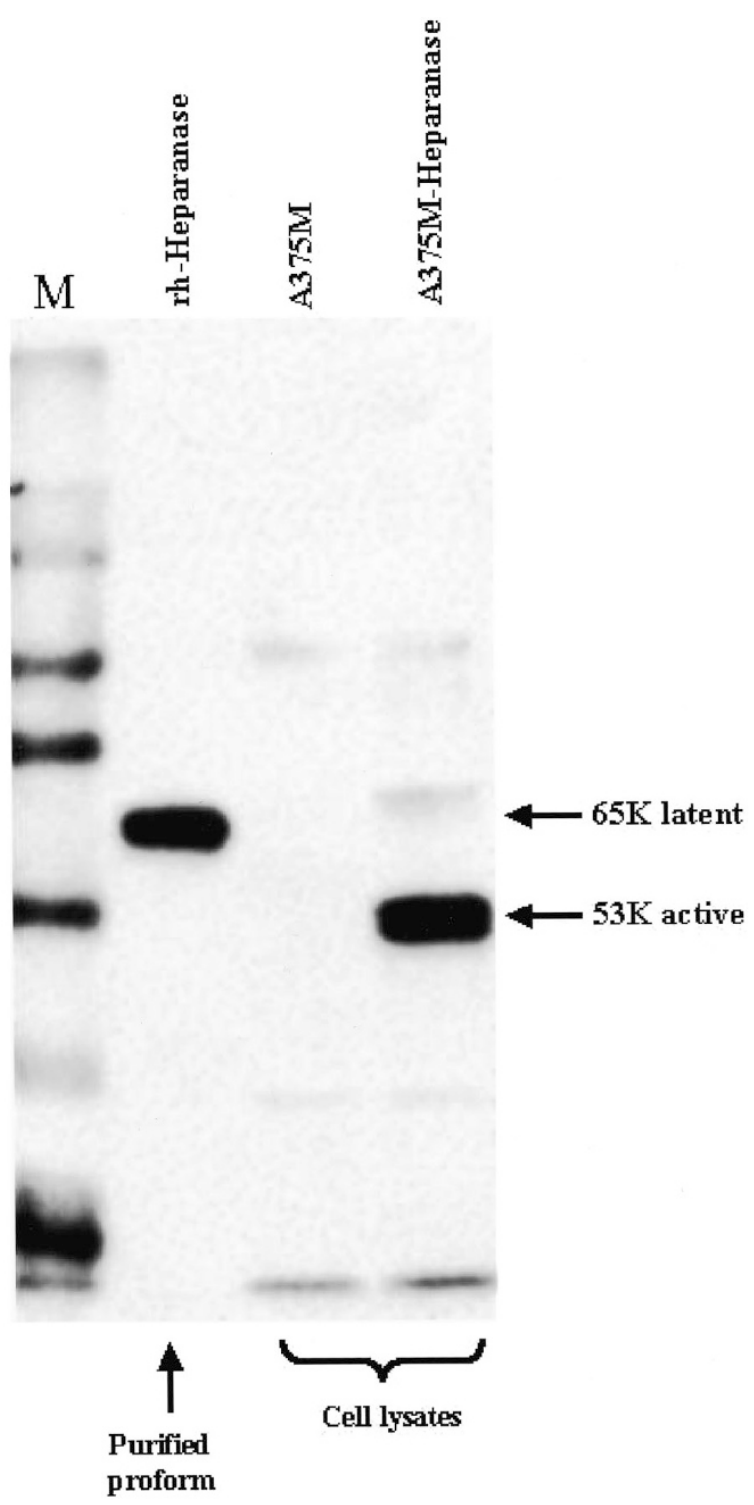

Figure 7.

Western blot analysis of human heparanase. Anti-human heparanase mAb reacted with both the $65-\mathrm{kDa}$ proform and the $53-\mathrm{kDa}$ mature form of the human recombinant heparanase.

\section{Acknowledgement}

We are grateful to Dr. Shunichiro Taniguchi for his generous gift of heparanase mAb.

\section{References}

Adachi $\mathrm{Y}$, Itoh $\mathrm{F}$, Yamamoto $\mathrm{H}$, Matsuno $\mathrm{K}$, Arimura $\mathrm{Y}$, Kusano M, Endoh T, Hinoda Y, Oohara M, Hosokawa M, and Imai K (1998). Matrix metalloproteinase matrilysin (MMP-7) participates in the progression of human gastric and esophageal cancers. Int J Oncol 13:1031-1035.

Ajani JA, Mansfield PF, and Ota DM (1995). Potentially resectable gastric carcinoma: Current approaches to staging and preoperative therapy. World J Surg 19:216-220.

Andela VB, Schwarz EM, Puzas JE, O'Keefe RJ, and Rosier RN (2000). Tumor metastasis and the reciprocal regulation of prometastatic and antimetastatic factors by nuclear factor kappa B. Cancer Res 60:6557-6562.

Bartlett MR, Underwood PA, and Parish CR (1995). Comparative analysis of the ability of leucocytes, endothelial cells and platelets to degrade the subendothelial basement membrane: Evidence for cytokine dependence and detection of a novel sulfatase. Immunol Cell Biol 73(2):113-124.

Carneiro F and Sobrinho-Simoes M (2000). The prognostic significance of amplification and overexpression of c-met and c-erb B-2 in human gastric carcinomas. Cancer 88:238240.

Endo K, Maejara U, Baba H, Tokunaga E, Koga T, Ikeda Y, Toh Y, Kohnoe S, Okamura T, Nakajima M, and Sugimachi K (2001). Heparanase gene expression and metastatic potential in human gastric cancer. Anticancer Res 21(5):33653369.

Finkel E (1999). Potential target found for antimetastasis drugs. Science 285:33-34.

Friedmann Y, Vlodavsky I, Aingorn H, Aviv A, Peretz T, Pecker I, and Pappo O (2000). Expression of heparanase in normal, dysplastic, and neoplastic human colonic mucosa and stroma: Evidence for its role in colonic tumorigenesis. Am J Pathol 157:1167-1175.

Hulett MD, Freeman C, Hamdorf BJ, Baker RT, Harris MJ, and Parish CR (1999). Cloning of mammalian heparanase, an important enzyme in tumor invasion and metastasis. Nat Med 5:803-809.

Inoue H, Mimori K, Utsunomiya T, Sadanaga N, Barnard GF, Ueo H, and Mori M (2001). Heparanase expression in clinical digestive malignancies. Oncol Rep 8:539-542.

Kussie PH, Hulmes JD, Ludwig DL, Patel S, Navarro EC, Seddon AP, Giorgio NA, and Bohlen P (1999). Cloning and functional expression of a human heparanase gene. Biochem Biophys Res Commun 261:183-187.

Lapierre F, Holme K, Lam L, Tressler RJ, Storm N, Wee J, Stack RJ, Castellot J, and Tyrrell DJ (1996). Chemical modifications of heparin that diminish its anticoagulant but preserve its heparanase-inhibitory, angiostatic, anti-tumor and anti-metastatic properties. Glycobiology 6:355-366.

Marchetti D, Li J, and Shen R (2000). Astrocytes contribute to the brain-metastatic specificity of melanoma cells by producing heparanase. Cancer Res 60:4767-4770.

Miao HQ, Elkin M, Aingorn E, Ishai-Michaeli R, Stein CA, and Vlodavsky I (1999). Inhibition of heparanase activity and 
tumor metastasis by laminarin sulfate and synthetic phosphorothioate oligodeoxynucleotides. Int J Cancer 83:424431.

Mollinedo F, Nakajima M, Llorens A, Barbosa E, Callejo S, Gajate C, and Fabra A (1997). Major co-localization of the extracellular-matrix degradative enzymes heparanase and gelatinase in tertiary granules of human neutrophils. Biochem J 327:917-923.

Nakajima M (1992). Heparanases and tumor metastasis. Tanpakushitsu Kakusan Koso 37:1753-1758.

Nakajima M, DeChavigny A, Johnson CE, Hamada J, Stein CA, and Nicolson GL. Suramin (1991). A potent inhibitor of melanoma heparanase and invasion. J Biol Chem 266:96619666.

Nakajima M, Irimura T, Di Ferrante D, Di Ferrante $\mathrm{N}$, and Nicolson GL (1983). Heparan sulfate degradation: Relation to tumor invasive and metastatic properties of mouse B16 melanoma sublines. Science 220:611-613.

Nakajima M, Sawada H, Yamada Y, Watanabe A, Tatsumi M, Yamashita J, Matsuda M, Sakaguchi T, Hirao T, and Nakano $H$ (1999). The prognostic significance of amplification and overexpression of c-met and c-erb B-2 in human gastric carcinomas. Cancer 85:1894-1902.

Nicolson GL, Irimura T, Nakajima M, and Estrada J (1983). Metastatic cell attachment to and invasion of vascular endothelium and its underlying basal lamina using endothelial cell monolayers. Symp Fundam Cancer Res 36:145-167.

Parish CR, Freeman C, Brown KJ, Francis DJ, and Cowden WB (1999). Identification of sulfated oligosaccharide-based inhibitors of tumor growth and metastasis using novel in vitro assays for angiogenesis and heparanase activity. Cancer Res 59:3433-3441.

Parish CR, Freeman C, and Hulett MD (2001). Heparanase: A key enzyme involved in cell invasion. Biochim Biophys Acta 1471:M99-M108.

Ries LA, Wingo PA, Miller DS, Howe HL, Weir HK, Rosenberg HM, Vernon SW, Cronin K, and Edwards BK (2000). The annual report to the nation on the status of cancer, 19731997 , with a special section on colorectal cancer. Cancer 88:2398-2424.

Schwartz GK (1996). Invasion and metastases in gastric cancer: In vitro and in vivo models with clinical correlations. Semin Oncol 23:316-324.

Senota A, Itoh F, Yamamoto H, Adachi Y, Hinoda Y, and Imai K (1998). Relation of matrilysin messenger RNA expression with invasive activity in human gastric cancer. Clin Exp Metastasis 16:313-321.
Shirakawa Y, Naomoto Y, Kimura M, Kawashima R, Yamatsuji T, Tamaki T, Hamada M, Haisa M, and Tanaka N (2000). Topological analysis of p21 WAF1/CIP1 expression in esophageal squamous dysplasia. Clin Cancer Res 6(2):541-550.

Tacchini L, Dansi P, Matteucci E, and Desiderio MA (2000). Hepatocyte growth factor signal coupling to various transcription factors depends on triggering of Met receptor and protein kinase transducers in human hepatoma cells HepG2. Exp Cell Res 256:272-281.

Tahara E (1995). Molecular biology of gastric cancer. World J Surg 19:484-488; discussion 489-490.

Tahara E (2000). Molecular aspects of invasion and metastasis of stomach cancer. Verh Dtsch Ges Pathol 84:43-49.

Toyoshima M and Nakajima M (1999). Human heparanase: Purification, characterization, cloning, and expression. J Biol Chem 274:24153-24160.

Uno F, Fujiwara T, Takata Y, Ohtani S, Katsuda K, Takaoka M, Ohkawa T, Naomoto Y, Nakajima M, and Tanaka N (2001). Antisense-mediated suppression of human heparanase gene expression inhibits pleural dissemination of human cancer cells. Cancer Res 61(21):7855-7860.

Vlodavsky I, Bar-Shavit R, Ishai-Michaeli R, Bashkin P, and Fuks Z (1991). Extracellular sequestration and release of fibroblast growth factor: A regulatory mechanism? Trends Biochem Sci 16:268-271.

Vlodavsky I, Friedmann Y, Elkin M, Aingorn H, Atzmon R, Ishai-Michaeli R, Bitan M, Pappo O, Peretz T, Michal I, Spector L, and Pecker I (1999). Mammalian heparanase: Gene cloning, expression and function in tumor progression and metastasis. Nat Med 5:793-802.

Walch ET and Marchetti D (1999). Role of neurotrophins and neurotrophins receptors in the in vitro invasion and heparanase production of human prostate cancer cells. Clin Exp Metastasis 17:307-314.

Yamamoto H, Adachi Y, Itoh F, Iku S, Matsuno K, Kusano M, Arimura $\mathrm{Y}$, Endo $\mathrm{T}$, Hinoda $\mathrm{Y}$, Hosokawa $\mathrm{M}$, and Imai $\mathrm{K}$ (1999). Association of matrilysin expression with recurrence and poor prognosis in human esophageal squamous cell carcinoma. Cancer Res 59:3313-3316.

Yamamoto $H$, Itoh F, Hinoda $Y$, Senota A, Yoshimoto M, Nakamura H, Imai K, and Yachi A (1994). Expression of matrilysin mRNA in colorectal adenomas and its induction by truncated fibronectin. Biochem Biophys Res Commun 201: 657-664. 